\title{
A bolíviai földgáz helyzete és aktuálpolitikai kérdései
}

\begin{abstract}
A 2000-es évek elejétől Latin-Amerikában egyre nagyobb kereslet mutatkozott a földgáz iránt, amely elsősorban a strukturális reformok okozta gazdasági növekedésnek volt köszönhető. Ennek az egyre növekvő igénynek Bolívia is haszonélvezője lehetne, hiszen jelentős földgáztartalékokkal rendelkezik, mégis gazdasági nehézségekkel küzd, amely földrajzi elhelyezkedéséből, továbbá bel- és külpolitikájából adódik. A tanulmány célja a dél-amerikai földgázpiac elemzése Bolivián keresztül, a vonatkozó politikai/történelmi tényezők, konfliktusok és a jövőbeli kilátások bemutatásával.
\end{abstract}

Kulcsszavak: Latin-Amerika, Bolívia, energia, földgáz

\begin{abstract}
Füzesi Kitti: Natural gas in Bolivia. Current situation and related political issues
There has been an increasing demand for natural gas in Latin America since the early 2000s mainly due to economic growth caused by structural reforms. Bolivia - as it has significant natural gas reserves - could also benefit from this trend, yet it struggles with economic difficulties mainly due to its geographical location, domestic and foreign policy. The aim of this study is to examine the South American natural gas market via Bolivia, as well as to analyse the related political / historical factors, conflicts, and future prospects.
\end{abstract}

Keywords: Latin America, Bolivia, energy, natural gas

\section{Bevezetés}

Dél-Amerika a 21. század elejére, kilépve az Amerikai Egyesült Államok (USA) árnyékából, önálló geopolitikai régióvá nőtte ki magát. Ebben nagy szerepet játszik Brazília mint a térség vezető állama. A régió ezt elsősorban gazdag erőforrás-tartalékainak köszönheti, amely iránt egyre nagyobb lett a kereslet Japán, Kína, az USA és Európa részéről. ${ }^{2}$

A kőolaj és a földgáz a modern gazdaságok egyik legfontosabb éltető ereje. Azonban ezek a nem megújuló energiakészletek végesek, és az eloszlásuk is nagyon egyenlőtlen. Az energiaforrások alapvető geopolitikai tényezővé válása döntően az 1970-es évek olajválságához köthető. Ez a tendencia napjainkban egyre inkább erősödik. Elmondható, hogy az országok egyik legfontosabb politikai célja az energiaforrások feletti ellenőrzés

Füzesi Kitti, a Nemzeti Közszolgálati Egyetem, Hadtudományi Doktori Iskola doktorandája.

Saul Bernard Cohen: Geopolitics: The Geography of International Relations. London, Rowman \& Littlefield, 2015.161. 
megszerzése. Mindezt jól mutatja, hogy a világ olajtartalékainak $90 \%$-át az államok vagy állami vállalatok ellenőrzik. ${ }^{3}$ Ugyanez megfigyelhető a földgáz terén is.

A cikk a bolíviai földgáz helyzetét mutatja be, először általános képet adva az országról, majd a dél-amerikai földgázpiacról és azon belül Bolívia szerepéről. Vázlatosan bemutatja a földgáz kitermelésének történetét, valamint a bolíviai Nemzeti Statisztikai Intézet kimutatásai segítségével elemzi a kitermelés alakulását 1990-től 2019-ig. Kitekintést tesz a bolíviai gázháború politikai okaira és következményeire, valamint arra is, hogyan képes a Bolívia és Chile közötti több mint száz éves konfliktus befolyásolni a földgáz szállításának és kereskedelmének jelenkori alakulását.

\section{Bolívia}

Bolívia Paraguay mellett a másik olyan dél-amerikai állam, amely nem rendelkezik tengerparttal. Az ország nevét a leghíresebb dél-amerikai szabadságharcosról, Simon Bolivárról kapta. Bár területileg a dél-amerikai kontinens 5. legnagyobb állama, mégis az egyik legritkábban lakott országnak számít, átlagos népsürüsége 10 fö/ $/ \mathrm{km}^{2}(2018) .{ }^{4} \mathrm{Az}$ ország területén belül a lakosság eloszlása egyenlőtlen, a teljes népesség alig több mint $70 \%$-a ${ }^{5}$ él a négy legnagyobb városban, a fövárosban La Pazban, Santa Cruzban, El Altóban és Cochabambában. Az ország társadalma igen fiatal, a medián életkor 25,3 év. ${ }^{6}$

Bolívia 1825-ben nyerte el függetlenségét a spanyol gyarmatosítókkal szemben, azonban az újonnan létrejött állam a dél-amerikai kontinens közepén, nem megfelelöen kijelölt határokkal a kezdetektől fogva ki volt téve az erősebb országok területszerzési törekvéseinek. Minden szomszédos állam szakított le magának Bolíviából, így az ország területe a függetlenedést követő kicsit több mint egy évszázad alatt a felére zsugorodott. A legnagyobb részt - mintegy 500 ezer $\mathrm{km}^{2} \mathrm{-t}$ - Brazília szerezte meg, nagyrészt tárgyalások útján. ${ }^{7}$ Mégsem ez a hatalmas területveszteség volt Bolívia számára a legfájdalmasabb. Az 1879-1883 között zajló salétrom- vagy csendes-óceáni háborúban Bolívia és Peru Chile ellen vereséget szenvedett, Chile megszerezte az Atacama-sivatag salétrommezőit, Bolívia pedig elvesztette tengeri kijáratát. Ez mind a mai napig komoly konfliktusforrás Chile és Bolívia között, mivel a dél-amerikai ország számára ez a veszteség jelentős külkereskedelmi hátránnyal jár. 1932-1935 között a Chaco-háború újabb vereséget és területveszteséget jelentett Bolívia számára. ${ }^{8}$

Ami a bolíviai gazdaságot illeti, az ország a többi dél-amerikai államhoz hasonlóan elsősorban mint nyersanyagexportőr kapcsolódott be a világgazdaságba. Az első kiviteli termék a gyarmati korszakban és a függetlenedést követően az ezüst volt, ami egészen a 20. századig uralta a bolíviai piacot. Ezt követően azonban egyre inkább háttérbe szorult

\footnotetext{
Velichka Milina: Energy Security and Geopolitics, Partnership for Peace Consortium of Defense Academies and Security Studies Institutes. Connections, 6. (2007), 4. 27-46. 27.

The World Bank: Population density. [online], Forrás: data.worldbank.org [2020. 04. 18.].

CIA: The World Factbook, Bolivia. [online], Forrás: www.cia.gov [2020. 04. 18.].

CIA: The World Factbook, Bolívia. (2020) i. m.

Szente-Varga Mónika: Társadalmi és politikai tendenciák Bolíviában a 21. században. Nemzet és Biztonság, (2016), 2. 3-16. 11 .

8 Lehoczki Bernadett: Bolívia: bel- és külpolitikai változások Evo Morales elnöksége alatt. Nemzet és Biztonság, (2009), 5. 3-13. 3-4.
} 
az új iparcikkel, az ónnal szemben, ami 1930-tól mintegy 40 éven keresztül Bolívia legfontosabb kiviteli cikkének számított, a teljes export több mint $60 \%$-át tette ki. ${ }^{9} \mathrm{Az}$ ón korszaka az 1980-as évekre véget ért, és a 21. századtól a dél-amerikai országban beköszöntött a földgázboom időszaka. Mára a bolíviai gazdaság motorja a földgáz, a földgázmezők pedig az ország délkeleti területein találhatók. ${ }^{10}$

Az ország belső energiafogyasztása meglehetősen alacsony, ennek okai egyrészt az alacsony népességszámban, másrészt a szegénységben és az erőforrásokhoz való hozzáférés hiányában keresendők. Az 1980-as években zajló általános gazdasági válság Bolíviát sem kímélte, amibe a katonai diktatúra is belebukott. 1982-től ismét civil vezetők irányítják az országot. Azonban Bolívia súlyosan eladósodott, a hiperinfláció 1985 első felében elérte a $8170 \%$-ot. ${ }^{11}$ Annak érdekében, hogy az államadósságot csökkenteni tudja, Bolíviának a Nemzetközi Valutaalaphoz (IMF) kellett fordulnia, a világszervezet által nyújtott támogatás feltétele viszont az volt, hogy a kormány mérsékelje a költségvetési kiadásokat. A bekövetkező privatizáció tovább mélyítette a társadalmi különbségeket, amelyek többek között a cochabambai vízháborúban törtek felszínre 2000-ben. Mindezek hatásaként megerősödött az ellenzék és vele együtt Evo Morales támogatottsága. Morales 2005-ös választási győzelme mérföldkőnek számított Bolívia történetében, bennszülött származása és nyíltan szocialista nézetei miatt. Három cikluson keresztül irányította a dél-amerikai országot, gazdaságpolitikájának pedig fontos része volt, hogy megerősítette az állam szerepét a legfontosabb ágazatokban, köztük a földgázszektorban is. ${ }^{12}$

\section{Dél-Amerika a földgázszektorban}

A 2000-es évek elejére Dél-Amerika a világ egyik leggyorsabban növekvő földgázpiacává vált. A növekedés részben a demokratizálódási folyamatoknak, valamint az 1980-as évek gazdasági válságait követő strukturális reformoknak volt köszönhetö, aminek eredményeként több, korábban a magánszektor elől elzárt ágazatot nyitottak meg (például az energiaszektort), és ez számos külföldi beruházást vonzott a régióba, valamint megnőtt az energiaigény. ${ }^{13}$ Természetesen ehhez hozzájárult, hogy a térség energetikai szempontból kedvező feltételekkel bír, jelentős kőolaj- és földgázkészlettel rendelkezik. Ahogy az 1. ábrán is látható, Latin-Amerikában található a világ földgáztartalékainak 4\%-a. A régión belül Venezuela áll az élen, a terület teljes készletének csaknem 79\%-át birtokolja. 2019-ben a térség földgázkitermelése 173,6 milliárd $\mathrm{m}^{3}$ volt, amely a világ kitermelésének 4\%-át tette ki. ${ }^{14}$ A táblázatból továbbá kiolvasható, hogy 2019-ben a dél- és közép-amerikai régió összes földgázfogyasztásának (165,4 milliárd m³ $) 77 \%$-át négy ország, Argentína, Brazília, Venezuela és Trinidad és Tobago adta. ${ }^{15}$ Bár regionális szinten a földgáz iránti

\footnotetext{
Lykke E. Andersen - Mauricio Meza: The Natural Gas Sector in Bolivia: An Overview. Andean Competitiveness Project. Documento de Trabajo No. 01, Universidad Católica Boliviana, 2001. 2.

10 Szente-Varga Mónika: Bolívia. In Szente-Varga Mónika - Bács Zoltán György (szerk.): Dél-Amerika a 21. században - társadalmi, gazdasági és politikai konfliktusok. Budapest, Dialóg Campus, 2019. 25.

11 Herbert S. Klein: Historia de Bolivia, De los Origenes al 2010. La Paz, Libreria Editorial „G.U.M., 2011. 271.

12 Szente-Varga (2019) i. m. 25-29.

13 South American Gas, Daring to tap the Bounty. International Energy Agency - OECD/IEA, 2003. 3.

14 BP Statistical Review of World Energy, $69^{\text {th }}$ Edition, 2020. pp. 32-36.
}

15 Uo. 
kereslet és a kínálat egyensúlyban van Latin-Amerikában, mégis annak eloszlása egyenlötlen. Dél-Amerikában Bolívia exportálja a legtöbb földgázt csővezetékeken keresztül, ami a térség gázimportjának 53\%-át teszi ki, míg a legtöbb cseppfolyósított földgázt Trinidad és Tobago szolgáltatja (2016) ${ }^{16}$ A dél-amerikai energiaellátásra jellemző, hogy elsősorban belső piacra termel, ezt jól mutatja, hogy 2016-ban a dél-amerikai földgázimport 73\%-át a régió országai, elsősorban Bolívia és Trinidad és Tobago biztosították, míg a fennmaradó $27 \%$ a térségen kívülről érkezett. ${ }^{17} \mathrm{Az}$ egyik legnagyobb importőr Chile, amely elsősorban az Egyesült Államokból szerzi be a cseppfolyósított földgázt.

1. táblázat: Földgázkészletek, termelés és fogyasztás mértéke Latin-Amerikában 2019-ben

\begin{tabular}{|c|c|c|c|}
\hline & $\begin{array}{l}\text { Bizonyítottan feltárt } \\
\text { készletek (milliárd m }{ }^{3} \text { ) }\end{array}$ & Termelés (milliárd m³) & Fogyasztás (milliárd m³) \\
\hline Argentína & 400 & 41,6 & 47,5 \\
\hline Bolívia & 200 & 15 & n. a. \\
\hline Brazília & 400 & 25,8 & 35,8 \\
\hline Kolumbia & 100 & 13,2 & 13,4 \\
\hline Peru & 300 & 13,5 & 8,3 \\
\hline Venezuela & 6300 & 26,5 & 26,5 \\
\hline Trinidad és Tobago & 300 & 34,6 & 17,5 \\
\hline Chile & n. a. & n. a. & 6,5 \\
\hline Dél- és Közép-Amerika & 8000 & 173,6 & 165,4 \\
\hline Világ összes országa & 198800 & 3989,3 & 3929,2 \\
\hline Százalékos arány & $4 \%$ & $4 \%$ & $4 \%$ \\
\hline
\end{tabular}

Forrás: BP Statistical Review of World Energy, 69 ${ }^{\text {th }}$ Edition, 2020. 32-36. alapján a szerző szerkesztése

\section{A földgáz helyzete Bolíviában}

Bolíviában a szénhidrogének története 1913-ra nyúlik vissza, ekkor kezdődtek meg az első fúrások, azonban a kitermelésre egészen 1921-ig kellett várni, amikor az észak-amerikai Standard Oil társaság bevonásával megindultak a munkálatok. Ennek oka az volt, hogy a bolíviai kormány nem rendelkezett elegendő tőkével és megfelelő technológiával a kő-

\footnotetext{
16 Nicolás Di Sbroiavacca et alii: Rol y perspectivas del gas natural en la transformación energética de América Latina, Aportes a la implementación del Observatorio Regional sobre Energías Sostenibles. [online], 2019. Comisión Económica para América Latina y el Caribe (CEPAL). Forrás: repositorio.cepal.org [2020. 04. 18.] 8.

17 Sbroiavacca et alii (2019) i. m. 9.
} 
olaj és a földgáz kitermeléséhez. A gázszektor fellendülését megakasztotta a Chaco-háború (1932-1935). Ennek kitörésében a gazdasági világválság keltette általános feszültségek mellett minden bizonnyal szerepet játszott a Bolíviában fúró Standard Oil és a Paraguayban dolgozó British Royal Dutch Shell közötti versenyfutás a térségben feltételezett olajkészletekért. A háborús veszteségek ${ }^{18}$ tovább rontották a Standard Oil megítélését. ${ }^{19} 1936$. december 21-én a bolíviai kormány létrehozta saját állami olajvállalatát, a Yacimientos Petroliferos Fiscales Bolivianost (YPFB). Végül a Standard Oil vállalatot a bolíviai kormány csempészettel vádolta meg, és kiutasította az országból, a földgázkitermelés pedig teljes mértékben az YPFB hatáskörébe került. Ez volt az első lépés a földgáz államosítása terén. Az 1940-es évek politikai instabilitása ellenére a földgázipar újabb lendületet vett, amelynek köszönhetően az 1950-es évekre a kőolaj és a földgáz kitermelése képes volt kielégíteni az országon belüli keresletet, Bolívia tehát importáló országból exportálóvá vált. ${ }^{20} \mathrm{~A}$ legnagyobb lelőhelyeket az 1960-as években fedezték fel Tarija és Cochabamba környékén. Miután az 1980-as években a korábbi exportcikk, az ón nemzetközi piaci értéke csökkent, a földgáz iránti kereslet pedig a latin-amerikai régióban megugrott, a bolíviai gazdaság is változtatásra kényszerült, és a földgázra alapozta jövőjét.

A földgáz kitermelése csak 1972-től, az Argentínával megkötött kétoldalú megállapodás eredményeként emelkedett meg jelentősen Bolíviában. Ahogy az az alábbi ábrán is jól kivehető, a kitermelésben számottevő mennyiségi ugrás a 2000-es évektől következett be. Az addig eltelt közel 30 évben gyakorlatilag stagnáló tendenciát mutató számok három év alatt megduplázódtak, és az 1990-es években körülbelül 3000 millió m³-röl több mint 6400 millió $\mathrm{m}^{3}$-re nőttek. ${ }^{21} \mathrm{~A}$ kitermelés mértéke pedig a további másfél évtizedben is - minimális megingással a 2008-as válság idején - meredeken ívelt felfelé. Ez a nagyarányú növekedés a szomszédos Brazília növekvő energiaszükségleteihez volt köthető. ${ }^{22} 2010$ után azonban a latin-amerikai gazdasági növekedés lassulni kezdett, az évtized közepétől negatívba fordult, majd stagnált. ${ }^{23} \mathrm{Ez}$ Bolívia földgázkitermelésén, általánosságban pedig az ország gazdaságán szinte azonnal éreztette hatását.

18 A Chaco-háborúban 50 ezer bolíviai vesztette életét a harcok, a vízhiány vagy betegségek következtében. A háború a területvesztésen túl gazdasági csapást jelentett az ország számára, mindezt pedig tovább tetézte, hogy nem találtak kőolajat a térségben. Lykke E. Andersen et alii: Natural Gas and Inequality in Bolivia after Nationalization. Development Research Working Paper Series, (2006), 5. 4-5.

19 Herbert S. Klein: Bolivian Oil and Natural Gas under State and Private Control, 1920-2010. Bolivian Studies Journal, 20. (2014), 141-164. 146-147.

20 Contexto Histórico de YPFB. [online], Forrás: www.ypfb.gob.bo [2020. 04. 25.].

${ }^{21}$ INE: Instituto Nacional de Estadística, Estado Plurinacional de Bolivia. [online], Forrás: www.ine.gob.bo [2020. 05. 02.].

22 Klein (2014) i. m. 143-144.

23 The World Bank: GDP growth (annual \%) Latin America and the Caribbean. [online], Forrás: data.worldbank.org [2020. 05. 08.]. 


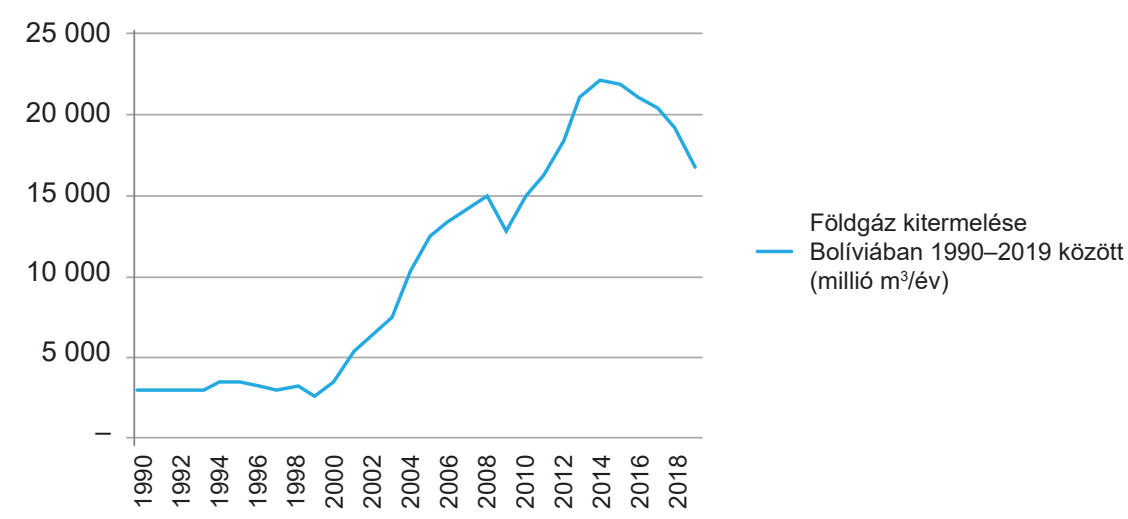

1. ábra: Földgáz kitermelése Bolíviában 1990-2019 között

Forrás: Bolivia - Produccion de Petroleo y Gas Natural segun Año y Mes 1990-2020, INE: Instituto Nacional de Estadística, Estado Plurinacional de Bolivia [online], Forrás: ine.gob.bo [2021.02.26.] adatai alapján a szerző szerkesztése

Bolíviában 2016-ban az addig feltárt 65 gázmezőből 41 működött. Az itt kitermelt földgáz 25\%-át használták fel országon belül, a többi 75\%-ot pedig exportálták. Bolíviában a primer energiafogyasztás $81 \%$-át a földgáz látja el. ${ }^{24}$ A szénhidrogének meghatározó, ugyanakkor a világpiaci igények és körülmények függvényében módosuló szerepét jól mutatja, hogy Bolívia exportjának 2013-ban közel felét adták (48\%), 2015-ben is még nagyon magas aránnyal számolhatunk (42\%), két évvel később azonban már csak 32\% (2017), bár még így is a kivitel egyharmadát teszik ki. ${ }^{25}$

\section{A bolíviai gázháború és annak előzményei}

1996-ig Bolíviában az állami olajipari társaság rendelkezett minden joggal a földgáz feltárása és kitermelése felett. Ezt követően azonban Gonzalo Sánchez de Lozada és utódja, Hugo Banzer (1997-2001) úgy döntöttek, hogy új befektetési alapokat teremtve felosztják a vállalatot, magánszemélyeknek kínálva részesedést benne. A privatizáció, vagy ahogy Lozada nevezte, a tőkésítés politikája azon alapult, hogy a gazdaság beindítása és munkahelyek teremtése érdekében Bolíviának mint tőkehiányos gazdaságnak ösztönöznie kell a külföldi befektetéseket. 1996-ban a kormány elfogadta az „1731. számú szénhidrogéntörvényt" ennek értelmében a külföldi befektetőknek (például a brazil Petrobras vagy a spanyol Repsol YPF) a földgáz kitermeléséből és értékesítésből származó bevételből csupán 18\%-ot kellett visszajuttatniuk a bolíviai államnak jövedékként. ${ }^{26} \mathrm{~A}$ szintén ebben az évben elfogadott 1689-es számú törvény 30. cikkelyének értelmében pedig amennyiben a szén-

\footnotetext{
Sbroiavacca et alii (2019) i. m. 17.

OEC: Bolivia. [online], Forrás: oec.world [2020. 04. 25.].

26 A korábbi törvény szerint a visszajuttatandó jövedék 50\% volt. Forrás: Lilón Domingo: A latin-amerikai politikai változások belső és nemzetközi kontextusa, Külügyi Szemle, (2008), 3. 91-107. 97-98.
} 
hidrogénkészletek olyan területen találhatók, amelyek esetében nincs megfelelően kiépített infrastruktúra - márpedig Bolíviában a gázmezők többsége nehezen megközelíthető helyen van - akkor legfeljebb tíz évig a kitermelést végző cég tulajdonát képezi a megtalált szénhidrogénkészlet. ${ }^{27} \mathrm{~A}$ fenti két törvénnyel a kormány az új lelőhelyek feltárását, a kitermelést és az infrastruktúra kiépítését akarta ösztönözni a külföldi befektetések révén, de az állampolgárok többsége úgy értelmezte, hogy az a bolíviai alkotmánnyal némiképp ellentmondott, ugyanis utóbbi leszögezi, hogy a bolíviai állam a tulajdonosa minden olyan természeti erőforrásnak, amely az ország területén, a föld alatt található, illetve azoknak is, amelyek ipari feldolgozás alatt állnak. Ezért a bolíviaiak egyre nagyobb hányada érezte úgy, hogy kizsákmányolás és átverés áldozatai lettek, és változást akartak. ${ }^{28}$ Azt szerették volna, hogy az ásványkincsekből származó haszon az országban maradjon, és ebből a vagyonból ők is részesülhessenek, azaz az ország természeti kincsei magát az országot gazdagítsák, és javítsák az ott élők életminőségét. Mindez hozzájárult ahhoz, hogy az őslakosok egyre aktívabban kívántak részt venni a helyi szintű erőforrások elosztásában és a politikai életben. Eleinte inkább csak arra törekedtek, hogy a már meglévő politikai pártok felvegyék őket a helyi jelöltek listájára, majd saját pártokat kezdtek alapítani. Ekkor került a politikába Evo Morales is. ${ }^{29} \mathrm{~A}$ társadalmi feszültségek kiéleződése és a politikai életben bekövetkező fenti változások vezettek a 2003. szeptember 19-tôl október 17-ig tartó eseményekhez, amelyeket leginkább a bolíviai gázháború néven emlegetünk, és amelynek legfőbb célja a földgáz visszaszerzése, teljes államosítása volt. Szeptember 19-én a Coordinadora de Recuperación y Defensa del Gas nevü szervezet országszerte tüntetéseket szervezett a kormány legújabb tervezete ellen, amely lehetővé tette volna, hogy brit és spanyol transznacionális vállalatok szállítsák a bolíviai földgázt az Egyesült Âllamokba Chilén keresztül, és amelyből a dél-amerikai állam csak igen csekély hasznot szerezhetett volna. ${ }^{30} \mathrm{~A}$ zavargásokat a kormány a fegyveres erő bevetésével fékezte meg, az akcióban azonban 60 ember vesztette életét, és további 400 állampolgár sérült meg. ${ }^{31}$ Sánchez de Lozada elnök lemondani kényszerült, és alelnöke, Carlos Mesa vette át az ország irányítását.

Mesa 2004-ben népszavazást tartott, ebben a bolíviaiaknak öt kérdésben kellett kinyilvánítaniuk véleményüket. Az első kérdésben a Lozada által 1996-ban bevezetett 1689-es számú Szénhidrogén törvény ${ }^{32}$ hatályon kívül helyezéséről kérdezték a lakosságot. A másodikban arra kellett válaszolniuk, hogy egyetértenek-e azzal, hogy az állam visszaszerezze az ellenőrzést a teljes szénhidrogén-kitermelésben, míg a harmadik kérdés az volt, hogy egyetértenek-e azzal, hogy a Lozada által részben privatizált YPFB újra állami tulajdonú vállalat legyen, és ezáltal a kormány a szénhidrogén-kitermelés teljes vertikumában részt tudjon venni. A negyedik kérdés lényege, hogy a lakosság támogatja-e Mesa azon politikai

Bolivia: Ley de Hidrocarburos, 30 de abril de 1996. [online], 1996. 04. 30. Forrás: www.lexivox.org [2020. 09. 23.].

Lilón (2008) i. m. 98-99.

29 Ann Chaplin: Social movements in Bolivia: from strength to power. Community Development Journal, 45. (2010), 3. 350 .

30 Tom Lewis: Bolivia’s gas war. [online], International Socialist Review, 36. (2004), online ed. Forrás: isreview.org [2020. 04. 25.].

31 Linda Farthing: A Surprise Win for the Victims of Bolivia's Gas War. [online], 2018. 04. 06. Forrás: nacla.org [2020. 04. 25.].

32 A törvény értelmében a bolíviai állam ellenőrzése a szénhidrogének felett a korábbi 50\%-ról 18\%-ra csökkent, valamint kötelezővé tette az ágazatban a társasági jövedelemadót. Forrás: María Lasa Aresti: Oil and Gas Revenue Sharing in Bolivia. Natural Resource Governance Institute, 2016. 12. 
célját, amely a földgázt stratégiai eszközként használná fel ahhoz, hogy szuverén útvonalat szerezzen a Csendes-óceánig. Végül az utolsó pontban az elnök arra volt kíváncsi, hogy az állampolgárok egyetértenek-e azzal, hogy Bolívia egy olyan nemzeti politika keretében exportáljon földgázt, amely elsősorban a belső földgázigényt fedezi, ösztönzi a földgáz ipari felhasználását az ország területén, valamint a gáz kiviteléből és az iparosodásból származó hasznot az állam az oktatás, az egészségügy és az úthálózat fejlesztésére, valamint munkahelyteremtésre fordítaná. ${ }^{33} \mathrm{Az}$ első három kérdéssel a szavazók több, mint 85\%-a egyetértett, míg a 4 . és az 5 . kérdés jóval kevesebb támogatást kapott. ${ }^{34}$ Ebben közrejátszott, hogy a Morales vezette MAS arra kérte az embereket, hogy a fenti két kérdésre nemmel válaszoljanak. Egy évvel a népszavazást követően a kongresszus elfogadta az új szénhidrogéntörvényt, amiben növelte az állami jogdíjakat (a korábbi 18\%-ról ismét 50\%-ra) ${ }^{35}$ a gázkitermelésben, de ez nem jelentette a szektor várt teljes államosítását. Az új törvény elismerte a földgázt, mint stratégiai erőforrást, amely kiemelten fontos szerepet játszik az ország szociális és gazdasági fejlődésében, valamint a külpolitikában, beleértve a csendes-óceáni kijárat elérését is. ${ }^{36}$ 2005-ben az újabb tüntetéshullámok hatására Mesa is távozott az elnöki pozícióból, helyét pedig a Legfelsőbb Tanács elnöke, Eduardo Rodríguez vette át. A 2005-ös választásokon a szavazatok 53,74\%-át megszerző Evo Morales lett Bolívia új elnöke. ${ }^{37} \mathrm{Ez}$ volt az első alkalom, hogy a katonai diktatúra éveit követően egy elnökjelölt az első fordulóban meg tudta szerezni a szavazatok több mint felét, így nem került sor második körös voksolásra. Morales győzelméhez hozzájárult, hogy választási programjában szerepelt a földgáz államosítása, amely egybeesett a bolíviaiak többségének követelésével. ${ }^{38}$

2006. május 1-jén Morales rendeletben be is vezette a földgáz államosítását, ettől kezdve a Bolíviában kitermelést végzö vállalatokat kötelezte arra, hogy 180 napon belül az YPFBnek adják át a szénhidrogén-kitermelést. Ezt követően a bolíviai állam lett a legnagyobb szénhidrogénmezők 82\%-ának kizárólagos tulajdonosa, a többi esetben pedig 60\%-os többségi tulajdont szerzett. ${ }^{39}$ Morales intézkedései azonban hátrányosan érintették a szomszédos Brazíliát és Argentínát, valamint Spanyolországot is, mivel ezen államok vállalatai voltak azok, amelyek leginkább részt vettek a bolíviai földgáz kitermelésében. Végül hosszas tárgyalások után a többségük aláírta az új szerződést a bolíviai kormánnyal, és folytatták a kitermelést, de számos nemzetközi cég a belpolitikai bizonytalanság és a szénhidrogénkészlet állami kisajátítása miatt korlátozta az új beruházásokat a bolíviai földgázpiacba. A külföldi befektetések hiánya pedig leginkább abban mutatkozott meg, hogy kevés új lelöhelyet fedeztek fel és vontak be a kitermelésbe. Mivel az ország egyik legjelentősebb exportcikkének a szénhidrogének számítanak, Bolíviát súlyosan érintette a globális olajárak csökkenése. ${ }^{40} \mathrm{~A}$ bevételkiesés ellensúlyozása érdekében felmerült a Paraguayba és Uruguayba

\footnotetext{
Astrid Arrarás - Grace Deheza: Referéndum del gas en Bolivia 2004: mucho más que un referéndum. Revista de Ciencia Politica, 25. (2005), 2. 161-172. 165.

34 Alexey Sidorenko: Bolivia. Gas Referendum. [online], 2004. Forrás: www.electoralgeography.com [2020. 05. 02.].

35 Anouk Honoré: South American Gas Markets and the role of LNG. Oxford Institute for Energy Studies, 2016. 97.

36 Bolivia: Ley de Hidrocarburos, 17 de mayo de 2005. [online], 2005. 05. 17. Forrás: www.lexivox.org [2020. 09. 23.].

37 Szente-Varga (2016) i. m. 7.

38 Maite Rico: Victoria arrolladora de Evo Morales, El candidato de la izquierda gana la presidencia boliviana con 20 puntos de ventaja sobre el conservador Quiroga. [online], 2005. 12. 20. Forrás: El País [2020. 05. 02.].

39 Lilón (2008) i. m. 99.

40 2015-ben egy év alatt 34,4\%-kal csökkentek a földgázexportból származó bevételek. Honoré (2016) i. m. 99.
} 
irányuló export megvalósítása, ehhez azonban gázvezetékekre lett volna szükség. Továbbá a kormány tervbe vette, hogy a földgáz egy részét cseppfolyósított földgázként értékesítse, ehhez azonban tengeri kijáratra lenne szüksége, ami Chilén vagy Perun keresztül vezetett volna. Bár gazdaságilag a Chilén keresztül történő export lett volna a kedvezőbb, a két ország között fennálló politikai konfliktus és a magas költségek nem tették lehetővé ennek megvalósítását. ${ }^{41}$

\section{Bolívia és Chile kapcsolata}

A két ország közötti ellentétek a 19. század végére, a csendes-óceáni háborúra nyúlnak vissza. A fegyveres konfliktus után 1884-ben megkötött valparaísói szerződés értelmében Bolívia átadta Chilének Atacama tartományt, ezáltal elvesztette tengeri kijáratát. Ez Bolívia számára mind a mai napig fájó pont és a két ország közötti kapcsolatra is rányomta a bélyegét. 1904-ben a két állam vezetői megállapodást írtak alá, amelyben Chile egy olyan vasútvonalat biztosított Bolívia számára, amely összeköti La Pazt Arica kikötőjével, ez pedig a bolíviaiaknak a legfontosabb gazdasági kapcsolatot jelentette a külvilággal. ${ }^{42} \mathrm{Az}$ ezt következő évtizedek sem voltak azonban teljesen konfliktusmentesek. 1978-ban Bolívia és Chile megszakította egymással a diplomáciai kapcsolatot. Ehhez hozzájárult, hogy ekkor volt a csendes-óceáni háború kitörésének századik évfordulója, amely még inkább elmérgesíttette a kétoldalú nexust. Bár szinte folyamatosan történtek kísérletek - leginkább a bolíviai kormány részéről - a vitás kérdés rendezésére, ez a probléma megoldatlan maradt, és 2002-ben ismételten kicsúcsosodott. ${ }^{43}$

A bolíviai kormány 2002-ben napirendre tüzte egy gázvezeték megépítését, amely Chilén át érne ki a Csendes-óceánhoz (mivel itt volt a legrövidebb útvonal), amivel pedig lehetővé vált volna a földgáz szállítása az Egyesült Államokba. Ez a tervezet azonban hatalmas ellenkezést váltott ki Bolíviában. A terv ellenzői - alapvetően politikai okokból - hoszszabb és költségesebb útvonalat javasoltak, tehát hogy a vezetéket nem Chilén, hanem Perun keresztül kellene eljuttatni a Csendes-óceánig. Érveik között szerepelt, hogy a vezeték megépítése hozzájárulhatna Bolívia északi területeinek gazdasági fellendüléséhez. A kormány viszont az olcsóbb és pragmatikusabb megoldás felé hajlott, lényegében tehát hajlandó lett volna földgázt eladni Chilének a tengeri kijáratért cserébe. A tárgyalásoknak a gázháború vetett véget. ${ }^{44}$

A két ország közötti fenti konfliktus Chile számára energetikai szempontból hátrányos. 2015-ben Chilében az átlagos napi gázkitermelés 3,1 millió $\mathrm{m}^{3}$ volt, míg a napi fogyasztás 13,4 millió $\mathrm{m}^{3}{ }^{35}$ ebből is jól látható, hogy a dél-amerikai állam jelentős gázimportra szorul. Az ország éves gázfogyasztásának csupán 23\%-át fedezi saját készlete, a többi 77\%-ot kül-

\footnotetext{
41 Honoré (2016) i. m. 97-99.

42 Az építési munkálatok 1913-ban értek véget, attól kezdve a bolíviai teherszállítás egyik fontos útvonala volt. A vasútvonal még mindig üzemel, de mára már leginkább turisztikai attrakcióként szolgál. FCALP cumple 107 años de historia al servicio de la región y del país. [online], Forrás: efe.cl [2021. 02. 26.].

43 Aparajita Gangopadhyay: From Land Wars to Gas Wars: Chile-Bolivia Relations and Globalisation. India Quarterly, 70. (2014), 2. 139-144.

44 Gangopadhyay (2014) i. m. 144.

45 Sbroiavacca et alii (2019) i. m. 24.
} 
földről kell beszereznie. ${ }^{46} \mathrm{~A}$ világ országainak földgázkészletét figyelembe vevő „ranglistán” Chile az 51., míg Bolívia a 38. helyen áll, saját készletük a világ összes földgázkészletének $0,05 \%$-át, illetve $0,2 \%$-át adja. ${ }^{47}$

Chile egészen a 2000-es évekig alapvetően nem támaszkodott a földgáz alapú energiaellátásra - például 1996-ban földgáz az ország energiafelhasználásának csak 8\%-át ${ }^{48}$ adta - azonban a növekvő energiaigény és a vízenergia megbízhatatlansága egyre inkább arra ösztönözte az ország vezetését, hogy átalakítsa energiapolitikáját és növelje a földgáz felhasználását. Mivel Bolíviától a több mint egy évszázados konfliktus miatt Chile nem tudott földgázt vásárolni, Argentínához fordult, és már az 1990-es években megkezdődött a gázvezetékek kiépítése a két ország között. A bolíviai gázháború azonban megnehezítette az argentin-chilei üzletet, ugyanis Argentína Chilének a Bolíviától vásárolt földgázt adta el, ezt pedig a bolíviai kormány nehezményezte. Különösen azért, mert 2004-ben, amikor egy újabb megállapodást kötött Argentínával a földgázszállításról a bolíviai kormány, kikötötte, hogy Argentína a „bolíviai földgáz egyetlen molekuláját sem” adhatja tovább Chilének. ${ }^{49}$

Chilének a bolíviai földgáz gazdasági és energiabiztonsági szempontból lenne előnyös, könnyebb és olcsóbb is lenne a szomszédos országtól beszereznie azt. Bolívia ugyanakkor új, tartós kereskedelmi kapcsolatot alakíthatna ki a közeli Chilével, hiszen annak hosszú távon szüksége van gázra. Chilén keresztül pedig a Csendes-óceánig érö gázvezetékkel további jelentős hasznot szerezhetne a nemzetközi piacra való kilépéssel. Utóbbira már csak azért is szüksége lehet, mert Argentína egyre kevésbé igényli a gázimportot saját földgázkitermelésének növekedése miatt. Nem elhanyagolható az sem, hogy Bolíviának szüksége van a külföldi tőke bevonására a kitermelés növelése érdekében, Chile pedig ebben a tekintetben is kedvező befektető lenne.

A chilei-bolíviai bilaterális viszonyt számos próbálkozás ellenére nem sikerült még rendezni. 2012-ben Bolívia a hágai Nemzetközi Bírósághoz fordult, 2018-ban született meg az ítélet, amelynek értelmében a Bíróság kimondta, hogy Chilét nem lehet arra kötelezni, hogy tárgyaljon Bolíviával a tengeri kijáratról, az ügy további megoldását pedig visszaadta a két ország kezébe. ${ }^{50}$

\section{A bolíviai földgáz jelenlegi helyzete}

A bolíviai földgáz két legnagyobb felvásárlója Brazília és Argentína. Brazíliával még 1999-ben kötött egy 20 évre szóló szerződést Bolívia a földgáz vezetéken történő szállításáról. A több mint $3000 \mathrm{~km}$ hosszú vezeték megépítése igen költséges és hosszú folyamat volt. A 20 éves megállapodás 2019-ben lejárt, amit Brazília nem újított meg. Bolívia számára Brazília továbbra is kereskedelmi partner marad, de a korábbinál kisebb mértékben. A másik fontos importálója a bolíviai földgáznak Argentína. A megkötött kétoldalú szerző-

46 Sbroiavacca et alii (2019) i. m. 24.

47 Natural Gas Reserves by Country. [online], Forrás: www.worldometers.info [2020. 04. 25.].

48 Gangopadhyay (2014) i. m. 145.

49 David R. Mares: Natural gas pipelines in the Southern Cone. In David G. Victor - Amy M. Jaffe - Mark H. Hayes (eds.): Natural Gas and Geopolitics, From 1970 to 2040. New York, Cambridge University Press, 2006. 169-201. 179.

50 Stephanie van den Berg - Aislinn Laing: World Court: Chile not forced to negotiate over Bolivia sea access. [online], 2018. 10. 01. Forrás: www.reuters.com [2020. 04. 26.]. 
dés 2026-ig van érvényben, de Argentína (Brazíliához hasonlóan) egyre inkább az önellátásra törekszik a földgáz terén, és csökkenteni szeretné a Bolíviából vásárolt szénhidrogén mennyiségét. ${ }^{51}$

Éppen ezért Bolíviának érdekében áll új kereskedelmi partnerek után nézni, elsősorban a szomszédos országok között. A legnagyobb potenciális felvásárló Chile lenne, amely az egyik legstabilabb gazdasággal rendelkezik Dél-Amerikában, de a korábban már tárgyalt konfliktus miatt a bolíviai kormány egyelöre nem hajlandó Chilének földgázt eladni. További nyitási lehetőség lenne Peru. A szomszédos Paraguayjal is tárgyalások kezdődtek az elmúlt időszakban egy gázvezeték megépítéséről, amely 2024-re készülhetne el. ${ }^{52}$

Ugyanakkor azt is fontos megjegyezni, hogy bár Morales a szénhidrogének teljes államosítására törekedett, a jelentős földgáztartalékokkal rendelkező dél-amerikai államnak a kitermeléshez külföldi technológiára és befektetőkre lenne szüksége. 2019. év végén Morales lemondott az elnöki pozícióból, és elmenekült az országból, a választásokig a hivatalos államfö Jeanine Añez lett. Az eredetileg május 3-ára kiírt választásokat azonban a bolíviai kormány a koronavírus-járvány miatt egyelőre elhalasztotta. ${ }^{53}$ Uj kormány hiányában a több mint 100 éve húzódó konfliktus és a földgázkérdés megoldása még várat magára.

\section{Összegzés}

Bolívia Paraguay mellett a másik olyan állam Dél-Amerikában, amelyik nem rendelkezik tengerparttal. Az ország gazdasági kihívásai részben földrajzi elhelyezkedéséből adódnak. A 2000-es évek elején jelentősen megnőtt a földgáz iránti kereslet Latin-Amerikában, a kialakult energiaigényhez Bolívia is alkalmazkodott, a földgáz lett a legfontosabb exportcikke. Bár az ország jelentős földgázkészletekkel rendelkezik, mégis gazdasági nehézségekkel küzd. Ennek elsősorban politikai okai vannak. A 2003-as bolíviai gázháború, majd Evo Morales elnökké választását követően lezajlott a földgáz teljes államosítása. Ennek azonban hátrányai is voltak, amelyek elsősorban abból adódnak, hogy Bolívia nem rendelkezik megfelelő technológiával a földgáz kitermelését illetően.

Miután a két legnagyobb felvásárló, Argentína és Brazília egyre inkább önellátásra törekszik földgázból, Bolíviának új kereskedelmi partnereket kell keresnie. A legfontosabb potenciális vevő Chile lenne, azonban a két ország között lévő több mint egy évszázados ellentét jelenleg nem teszi lehetővé a megállapodást. A regionálisan, politikailag, etnikailag is megosztott, pontosabban kettéosztott Bolíviában (hegyvidék és síkvidék) a tengerpart kérdése és a Chile iránti ellenszenv közös nevező, amire a bolíviai kormányok - függetlenül attól, hogy demokratikus vagy diktatórikus módon irányítottak - mindig is támaszkodtak.

Ahhoz, hogy az ország ki tudja elégíteni saját energiaigényét, valamint el tudja látni exportpiacát, újabb földgázlelőhelyeket kell feltárni és ott elindítani a kitermelést. Ehhez elsősorban külföldi befektetések szükségesek. A jelenlegi belpolitikai problémák nem

${ }^{51}$ ¿Qué debe hacer Bolivia con su gas después de Brasil y Argentina?. [online], 2020. 02. 18. Forrás: correodelsur.com [2020. 04. 27.].

52 Uo.

53 Bolivia delays presidential elections, mandates 14-day quarantine against virus. [online], 2020. 03. 21 . Forrás: france24. com [2020. 04. 30.]. 
kedveznek ennek a folyamatnak, ezért nagy szerepe lesz majd a koronavírus-járvány elmúltával megtartott választásokon győzni tudó új elnöknek abban, hogy milyen irányba mozdul el Bolívia nemzetközi megítélése.

\section{FELHASZNÁLT IRODALOM}

Andersen, Lykke E. - Johann Carlo - Robert Faris - Mauricio Medinaceli: Natural Gas and Inequality in Bolivia after Nationalization. Development Research Working Paper Series, (2006), 5.

Andersen, Lykke E. - Mauricio Meza: The Natural Gas Sector in Bolivia: An Overview. Andean Competitiveness Project. Documento de Trabajo No. 01, Universidad Católica Boliviana, 2001

Aresti, María Lasa: Oil and Gas Revenue Sharing in Bolivia. Natural Resource Governance Institute, 2016.

Arrarás, Astrid - Grace Deheza: Referéndum del gas en Bolivia 2004: mucho más que un referéndum. Revista de Ciencia Política, 25. (2005), 2. 161-172. DOI: https://doi.org/10.4067/S0718-090X2005000200008

Bolivia delays presidential elections, mandates 14-day quarantine against virus. [online], 2020. 03. 21. Forrás: france24.com [2020. 04.30.]

Bolivia: Ley de Hidrocarburos, 30 de abril de 1996. [online], 1996. 04. 30. Forrás: www.lexivox.org [2020. 09. 23.]

Bolivia: Ley de Hidrocarburos, 17 de mayo de 2005. [online], 2005. 05. 17. Forrás: www.lexivox.org [2020. 09. 23.]

Bolivia - Produccion de Petroleo y Gas Natural segun Año y Mes 1990-2020, INE: Instituto Nacional de Estadística, Estado Plurinacional de Bolivia. [online], Forrás: ine.gob.bo [2021. 02. 26.]

BP Statistical Review of World Energy, $69^{\text {th }}$ Edition, 2020.

Chaplin, Ann: Social movements in Bolivia: from strength to power. Community Development Journal, 45. (2010), 3. 346-355. DOI: https://doi.org/10.1093/cdj/bsq028

CIA: The World Factbook, Bolívia. [online], Forrás: www.cia.gov [2020. 04. 18.]

Cohen, Saul Bernard: Geopolitics: The Geography of International Relations. London, Rowman \& Littlefield, 2015.

Contexto Histórico de YPFB. [online], Forrás: www.ypfb.gob.bo [2020. 04. 25.]

Farthing, Linda: A Surprise Win for the Victims of Bolivia's Gas War. [online], 2018. 04. 06. Forrás: nacla.org [2020. 04. 25.].

FCALP cumple 107 años de historia al servicio de la región y del país. [online], Forrás: efe.cl [2021. 02. 26.]

Gangopadhyay, Aparajita: From Land Wars to Gas Wars: Chile-Bolivia Relations and Globalisation. India Quarterly: A Journal of International Affairs, 70. (2014), 2. 139-152. DOI: https://doi.org/10.1177/0974928414524651

Honoré, Anouk: South American Gas Markets and the role of LNG. Oxford Institute for Energy Studies, 2016. DOI: https://doi.org/10.26889/9781784670719

Klein, Herbert S.: Bolivian Oil and Natural Gas under State and Private Control, 1920-2010. Bolivian Studies Journal, 20. (2014), 141-164. DOI: https://doi.org/10.5195/bsj.2014.97

Klein, Herbert S.: Historia de Bolivia, De los Origenes al 2010. La Paz, Libreria Editorial „G.U.M., 2011.

Lehoczki Bernadett: Bolívia: bel- és külpolitikai változások Evo Morales elnöksége alatt. Nemzet és Biztonság, (2009), 5. 3-13.

Lewis, Tom: Bolivia’s gas war. International Socialist Review, 36. (2004), online ed. Forrás: isreview.org [2020. 04. 25.]

Lilón Domingo: A latin-amerikai politikai változások belső és nemzetközi kontextusa. Külügyi Szemle, (2008), 3. 91-107.

Mares, David R.: Natural gas pipelines in the Southern Cone. In David G. Victor - Amy M. Jaffe - Mark H. Hayes (eds.): Natural Gas and Geopolitics, From 1970 to 2040. Cambridge University Press, New York, 2006. 169-201. DOI: https://doi.org/10.1017/CBO9780511493492.007

Milina, Velichka: Energy Security and Geopolitics, Partnership for Peace Consortium of Defense Academies and Security Studies Institutes. Connections, 6. (2007), 4. 27-46. DOI: https://doi.org/10.11610/connections.06.4.03

Natural Gas Reserves by Country. [online], Forrás: www.worldometers.info [2020. 04. 25.]

OEC: Bolivia. [online], Forrás: oec.world [2020. 04. 25.]

¿Qué debe hacer Bolivia con su gas después de Brasil y Argentina?. [online], 2020. 02. 18. Forrás: correodelsur. com [2020. 04. 27.] 
Rico, Maite: Victoria arrolladora de Evo Morales, El candidato de la izquierda gana la presidencia boliviana con 20 puntos de ventaja sobre el conservador Quiroga. [online], 2005. 12. 20. Forrás: El País [2020. 05. 02.]

Sbroiavacca, Nicolásjj Di - Hilda Dubrovsky - Gustavo Nadal - Rubén Contreras Lisperguer: Rol y perspectivas del gas natural en la transformación energética de América Latina, Aportes a la implementación del Observatorio Regional sobre Energías Sostenibles. [online], 2019. Comisión Económica para América Latina y el Caribe (CEPAL). Forrás: repositorio.cepal.org [2020. 04. 18.]

Sidorenko, Alexey: Bolivia. Gas Referendum. [online], 2004. Forrás: www.electoralgeography.com [2020. 05. 02.]

South American Gas. Daring to tap the Bounty. International Energy Agency - OECD/IEA, 2003.

Szente-Varga Mónika: Bolívia. In Szente-Varga Mónika - Bács Zoltán György (szerk.): Dél-Amerika a 21. században - társadalmi, gazdasági és politikai konfliktusok. Budapest, Dialóg Campus, 2019. 25-40.

Szente-Varga Mónika: Társadalmi és politikai tendenciák Bolíviában a 21. században. Nemzet és Biztonság, (2016), 2. 3-16.

Van den Berg, Stephanie - Aislinn Laing: World Court: Chile not forced to negotiate over Bolivia sea access. [online], 2018. 10. 01. Forrás: www.reuters.com [2020. 04. 26.]

The World Bank: GDP growth (annual \%) Latin America and the Caribbean. [online], Forrás: data.worldbank. org [2020. 05. 08.]

The World Bank: Population density. [online], Forrás: data.worldbank.org [2020. 04. 18.] 